Article

\title{
The End-Purpose of Teaching History and the Curricular Inclusion of Social Problems from the Perspective of Primary Education Trainee Teachers
}

\author{
Delfín Ortega-Sánchez ${ }^{1, *(1)}$ and Joan Pagès Blanch ${ }^{2}$ \\ 1 Department of Specific Didactics, Faculty of Education, University of Burgos, 09001 Burgos, Spain \\ 2 Department of Language, Literature and Social Science Education, Autonomous University of Barcelona, \\ 08193 Bellaterra (Cerdanyola del Vallès), Spain; joan.pages@uab.cat \\ * Correspondence: dosanchez@ubu.es; Tel.: +34-947-111-832
}

Received: 26 December 2019; Accepted: 21 January 2020; Published: 28 January 2020

check for updates

\begin{abstract}
The principal objective of the present study is to analyze the representations of Primary Education trainee teachers $(n=232)$ involving the end-purposes of teaching History and, in particular, their views on the didactic treatment and curricular inclusion of social problems at this educational stage. A mixed investigation method is applied, which combines both qualitative and quantitative approaches. The results pointed to a predictive influence of the degree of importance attached to the didactic treatment of social problems and the frequency with which they were covered on the Degree Course, for the assessment of their explicit inclusion in the Social Sciences curriculum. Likewise, the educational potential of the social problems appeared to be unconnected to the most highly assessed end-purposes, which are related to the development of social, critical, and creative thought for participation and social intervention.
\end{abstract}

Keywords: end-purposes of history teaching; relevant social problems; teacher training; Primary Education; social thought

\section{Introduction}

Reflecting on the end-purposes of teaching History and the Social Sciences allows teachers to guide decision-making, promote certain student models, and establish coherent connection links between their thinking and their own teaching practice. Teachers, as agents of social change, should reflect on what are the end-purposes of the Social Sciences that they impart in order to promote this coherence (Hernández 2013). Therefore, defining them during the university education of future teachers, and analyzing the results of its educational practice, constitutes indispensable knowledge for didactic change (Abellán 2014).

The end-purposes of teaching History and the Social Sciences would have to be directed towards critical comprehension of the reality and social democratic intervention. On that point, teacher training programs would be fruitless without the curricular incorporation of social problems (Benejam and Pagès 1997), which would offer the necessary results and instruments for decision-making and social commitment (Pagès 2002; González 2013). From this perspective, a training in social, critical, and creative thought, and education for the practice of democratic citizenship would have to constitute the fundamental foundation of the end-purposes of teaching the Social Sciences at school. Curricular inclusion of social problems yields precisely the right material for training in social thought, critical positioning, and student decision-making.

There is no doubt that education for democratic participation appears linked to training in social thought (Canal et al. 2012). This thought "is development when people are confronted with social 
problems, which are those that take up most of our lives, but are given little attention at school" (Pagès and Santisteban 2014, p. 26). Social and environmental problems are, in effect, the ones that have to be proposed as relevant educational objectives, in such a way that academic knowledge is placed at the service of their treatment and analysis (García-Pérez 2014), with the purpose of thinking through reality and developing the social and historical conscience of students.

The end-purpose of covering social problems in the teaching of Social Sciences therefore begins with the need to gain a critical understanding of reality in increasingly heterogenous societies (Kello 2016) of the inescapable educational promotion of social justice, and to learn and to teach active participation, in a committed and responsible way in the construction of responses and alternatives (Ten Dam and Volman 2004; Levstik and Tyson 2008; Pagès and Santisteban 2014). Education for social intervention and precise participation, in consequence, of the curricular incorporation and the didactic treatment of social problems and socially alive questions (Evans and Saxe 1996; Hess 2004; Legardez 2003; Santisteban 2012; Pagès and Santisteban 2011), and the acquisition of necessary professional competences for teaching in and for democratic citizenship (Martínez and Moreno 2012).

Indeed, international scientific literature has been demonstrating that the teaching of social problems and controversial issues constitutes one of the most powerful tools for the promotion of active citizenship, the development and acquisition of critical-reflexive thinking skills (Misco 2013), and education for democratic citizenship (Pollak et al. 2017; Misco and Lee 2014), which are the main purposes of teaching Social Sciences. It has also evidenced, however, the complexities, risks, and interferences of emotional reactions in the learning of sensitive, delicate, controversial or controversial historical, geographical, or social issues (Jerome and Elwick 2019; Reiss 2019; Ho and Seow 2015; Washington and Humphries 2011; Swalwell and Schweber 2016).

Recent studies have advanced in the analysis of the strategies used by teacher educators in the teaching of controversial subjects (Nganga et al. 2020; Pace 2019), and in the curricular decision making of teachers on this teaching (Hung 2019; King 2009). In these advances, the adequacy of the discussion or the development of deliberative skills and conversational learning is confirmed as the most appropriate strategy for the didactic treatment of social problems or controversial issues (Claire and Holden 2007; Oulton et al. 2004; Hand and Levinson 2012; Ezzedeen 2008). The promotion of the discussion on specific social justice problems has also been approached from the use of controversial images or documentary in teacher training contexts, in order to question what happens or has happened in present and past societies (Hawley et al. 2016; Marcus Alan S. 2009).

Thinking socially about reality and its teaching requires a conscious and reflective selection of social content, capable of allowing its problematization by teachers, and its reconstruction and critical treatment by students. This selection would transcend/apply potentially acquired knowledge from the most everyday contexts to the most remote and provide alternatives, or open exploration paths, to problems (creative thinking).

The predominance in Spain and other Latin-American countries of a History based on the national hegemonic narrative is so overwhelming that not even those who claim changes in teaching and teacher training have raised this debate and developed strategies so that history ceases to be led by the leading minorities and becomes open to the common people, to the others, to the different (Villalón and Pagès 2013). According to the research of Ortega-Sánchez (2019) for the Spanish context, a strong curricular standardization is evident in teaching practice, similar to that indicated by Misco (2013). This didactic positioning coincides with other studies such as Pollak et al. (2017), who demonstrate the resistance of teachers to complex and relativize curricular content through controversy. The treatment of social problems in teacher training appears to be linked to the development of social criticism, to the acquisition of social competences and to education for a democratic and participative culture (Santisteban 2012). The social problems, controversial topics, and socially alive questions are presented as indispensable elements for the integral development of civic and citizen-based competences (De Alba Fernández et al. 2012), through their relation with training in social thought (Pagès and Santisteban 2011, 2014). The conflict as a key concept for the selection and sequencing of 
social content in schools offers an excellent opportunity (Huddleston 2005; Santisteban 2015) for the acquisition of social and citizen-based competences transferable to any contemporary social problem, from the past or in the future (Ortega-Sánchez and Pagès 2017a).

The most recent scientific literature on the treatment of social problems or controversial social questions in the Social Sciences classroom and their curricular inclusion emphasizes the need to "introduce students into large-scale social debates where different points of view exist, different interests are at stake, and where it is desirable that they construct their own opinions in that respect from a critical and reasoned perspective" (Díaz and Fuente 2017, p. 26). In this sense, there are pioneering investigations such as those of Martínez and Pagès (2017) and Martínez (2017) on the design and the implementation of didactic sequences on the basis of songs for the didactic treatment of relevant social problems in basic secondary education. In accordance with the results obtained in these investigations, teaching actions should be oriented towards reflection on present problems, and towards methodological change are positive. Songs, included as socio-cultural sources on the problematization of content, are proposed as good resources for both teaching and learning relevant social problems and, in consequence, for training in social thought.

The absence of social problems in the curriculum and in editorial publications limits the approach of students both to integral knowledge of social contents and to its usefulness for the comprehension of the world, as well as limiting its possibilities for interpretation and responses to the complexity that characterizes it. Work with social problems "permits a typology of analysis that includes the relative experience of the past and the expectations for the future in a present that is lived, and to consider the temporal relation on the basis of the analysis of changes and continuities observable from a comparative perspective" (Grau 2016, p. 59). The didactic consideration of social problems as content and curricular strategy will, all in all, favor the development of social thought on social reality in the form of reflection and analysis (Segall and Gaudelli 2007), decision-taking, and the proposal of solutions (Pagès 2015; Santisteban 2009).

In the comprehension and interpretation of the historicity of the present and in planning the social future, social problems would have to represent a fundamental curricular tenant, giving relevance to the contemporaneousness of the student (Pagès 2007). We agree with Pagès and Santisteban (2014) in considering the need to prioritize investigation into historic-social thought, and reflection and proposals for solving social problems. However, investigation is still scarce on "the formation of creative, alternative and divergent thought, or on capacities to seek solutions to social problems" (Pagès and Santisteban 2014, p. 26).

The investigation evidences the advantages of studying social problems in teacher training and their impact on the representations of students. Ascertaining the social representations of trainee teachers on contemporary social problems, and the type of social thought that they experience, constitutes one of the first supports with which to define the criteria that have to guide the teaching of Social Sciences thought out to instill an understanding of social reality and intervention (Ortega-Sánchez and Pagès 2017a). Nevertheless, "not only should we make known the social problems that are relevant to our students, but the way we do so and the way the students contemplate their representations in the practice of teaching are fundamental" (Santisteban 2015, p. 390).

In this context, the principal objective of the present study consists of analyzing the representations of Primary Education Spanish trainee teachers on the end-purposes of teaching History and, in particular, the didactic treatment of social problems and their inclusion in the curriculum at that educational stage. Likewise, it seeks to confirm the existence of a predictive relation between the representations of the students on the degree of importance attached to the didactic treatment of social problems, and the frequency with which they are covered in their Degree courses, for the assessment of their explicit inclusion in the Social Sciences curriculum for Primary Education. Finally, the research seeks to note potential differences in the assessment of the curricular inclusion of social problems as a function of the sex and the age of the students. 
On the basis of these objectives, the study seeks to contribute to the training of critical Social Sciences teachers capable of articulating reflexive practices adopting active and committed positions (Bronckbank and McGill 2007; Perrenoud 2011) on relevant social problems and socially alive questions.

\section{Methods}

\subsection{Participants}

The sample was composed of a total of 232 students (women: $f=135 ; 58.2 \%$; men: $f=97 ; 41.8 \%$ ), enrolled on the fourth course of the Degree of Primary Education teacher at the University of Burgos, with an average age of 22.67 years $(S D=0.64$; range 21-22). Its frequency and percentage distribution by age groups was as follows: group $1=21-22(\mathrm{f}=99 ; 42.7 \%)$; group $2=23-24(\mathrm{f}=111 ; 47.8 \%)$; and group $3=25-26(f=22 ; 9.5 \%)$.

Intentional criteria guided the selection of the sample, in accordance with the adaptation of the characteristics of the participants to the set objectives of the investigation: having enrolled on the fourth year of the Degree in Primary Education Teaching at the University of Burgos; and having completed the first phase of teaching practice contemplated in the teaching plan of the Degree course.

\subsection{Instrument}

The ad hoc design of the instrument that was applied consisted of a questionnaire with fifteen items: eleven scalar items with a response interval of one to ten points, one scalar item of measurement (age), and two categorical nominal items of measurement (sex and curricular mention). With the object of triangulating the quantitative results, the instrument was completed by an open question included in the questionnaire "Contents, procedures, objectives, end-purposes, and protagonists of History teaching at school" (Ortega-Sánchez 2017) (Table 1).

Table 1. EpHT Questionnaire and scale. Source: Authors.

\begin{tabular}{|c|c|}
\hline \multicolumn{2}{|r|}{ EpHT Questionnaire and Scale } \\
\hline \multicolumn{2}{|r|}{ Sociodemographic characteristics } \\
\hline \multicolumn{2}{|r|}{ 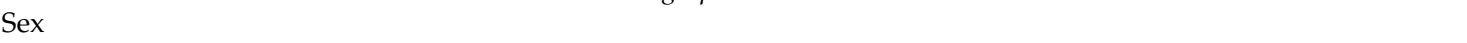 } \\
\hline \multicolumn{2}{|l|}{ Age } \\
\hline \multicolumn{2}{|r|}{ Degree course } \\
\hline c.1 & Values the frequency with which current social problems have been covered on the Degree course. \\
\hline c. 2 & The social problems have to be explicitly included in the curricular area of Primary Education Social Sciences. \\
\hline c.3 & $\begin{array}{l}\text { What level of importance do you attach to the didactic treatment of social problems in Primary Education? } \\
\text { EpHT (End-purposes of History teaching) }\end{array}$ \\
\hline c.4-1 & Help students to construct their own view of people and things (critical capacities of social analysis). \\
\hline c.4-2 & Awaken and develop (critical and creative) social thought in children. \\
\hline c.4-3 & Educate for social intervention and transformation in a process of continuous improvement of democratic life. \\
\hline c. $4-4$ & $\begin{array}{l}\text { Encourage learning, from a critical and reflexive point of view with the capacity for social comprehension } \\
\text { and analysis. }\end{array}$ \\
\hline c. $4-5$ & $\begin{array}{l}\text { Educate for the practice of democratic socialization, training students so that they can and wish to participate } \\
\text { in the problems of social reality. }\end{array}$ \\
\hline c.4-6 & Socialize students for their adaptation to the society in which they live. \\
\hline c.4-7 & Know the past for the construction of national identities (History as magistra vitae). \\
\hline c. $4-8$ & $\begin{array}{l}\text { Obey the rules and norms established by the society in which the students live. } \\
\text { Open question }\end{array}$ \\
\hline c.5 & $\begin{array}{l}\text { According to your criteria and the training on the Degree Course, what social end-purpose and what } \\
\text { objectives would have to be selected for the teaching of History in Primary Education at school? Give } \\
\text { your reasons? }\end{array}$ \\
\hline
\end{tabular}

The preparation of the EpHT scale began with the review of the scientific literature and, in particular, the works of Pagès (1994, 2002), Santisteban (2012), Ortega-Sánchez (2017), Abellán (2014), González (2013), and Hernández (2013). 
Both Cronbach's $\alpha$ and the coefficient of composite reliability and internal consistency, $\omega$, were determined, to check the reliability and internal consistency of the scale, and assuming the circumstance of normality and consistency of the data. The indices yielded satisfactory results $(\alpha=0.917 ; \omega=0.967)$.

In a first phase, an exploratory Principal Components Analysis (PCA) with varimax rotation was performed, in order to test the validity of the construct and the goodness of fit of the data. The type of factorial rotation in use applied the Kaiser rule to eigenvalues greater than 1 . This model permits the identification of correlative levels or theoretical relations between the variables that have been established, to reduce their number and to summarize the data in view of the objective under study.

With a view to understanding the factorization possibilities of the matrix, and prior to the analysis, we examined the matrix of correlations/covariables between variables, by applying Bartlett's test of sphericity, and the Kaiser, Meyer Olkin measurement index of sampling adequacy. The results obtained in the KMO test $(0.797)$ and in the sphericity test $\left(\chi^{2}{ }_{(28)}=4057.975 ; p=0.000\right)$ indicated the adequacy of the matrix to be factorized. The exploratory factor analysis identified two factors that explained $94.94 \%$ of the total variance. Values below 0.40 were used for the validation of the scale (Table 2).

Table 2. Rotated component matrix for the EpHT.

\begin{tabular}{llc}
\hline \multicolumn{1}{c}{ End-Purposes of History Teaching (EpHT) } & Component \\
\cline { 3 - 3 } & \multicolumn{1}{c}{$\mathbf{1}$} & $\mathbf{2}$ \\
\hline c.4-1 & $\begin{array}{l}\text { Help students to construct their own view of people and things (critical capacity for } \\
\text { social analysis) }\end{array}$ & 0.960 \\
c.4-2 & $\begin{array}{l}\text { Awaken and develop (critical and creative) social thought of the child } \\
\text { Educate for social intervention and transformation in a continuous process of } \\
\text { improvement of democratic life }\end{array}$ & 0.958 \\
c.4-3 & $\begin{array}{l}\text { From a critical and reflexive point of view, promote learning of capabilities and } \\
\text { understanding of social analysis }\end{array}$ & 0.956 \\
c.4-4 & $\begin{array}{l}\text { Educate for the practice of democratic socialization, training students so that they can } \\
\text { and wish to participate in the problems of social reality }\end{array}$ & 0.910 \\
c.4-5 & $\begin{array}{l}\text { Socialize students for their adaptation to the society in which they live } \\
\text { Know the past (History as magistra vitae) }\end{array}$ & 0.979 \\
c.4-7 & $\begin{array}{l}\text { Obey the rules and the norms established by the society in which the student lives } \\
\text { c.4-8 }\end{array}$ & 0.964 \\
\hline
\end{tabular}

In accordance with these results, in a second phase, we completed a confirmatory factor analysis. Having linked two errors of observation in factor 2, the goodness of fit values were acceptable for the following indices: NFI (=0.931), IFI (=0.935) and CFI (=0.935) (Figure 1).

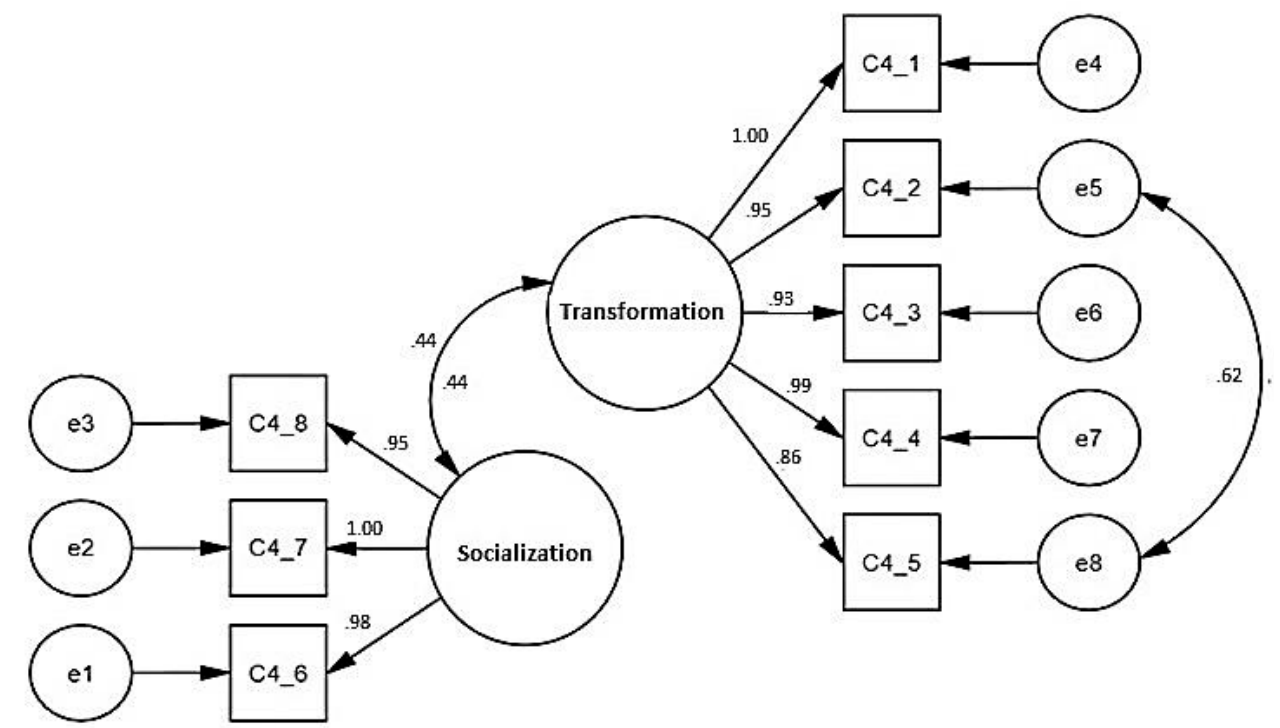

Figure 1. Latent, observed, and residual variables, and correlations of the EpHT scale. 
The results uphold the dimensional correspondence of the instrument designed with the two factors from both analyses:

1. Socialization (three items): The items linked with this dimension point to end-purposes in the teaching of Social Sciences oriented towards socialization, integration, and adaptation of the social environment to the students. Educational opportunities are not needed for active participation and social commitment towards relevant social problems or socially alive questions in the social reality of the students. It corresponds to a technical conception of the Social Sciences curriculum (Pagès 1994), in which a definite curricular model is explained, and to the maintenance of its status quo for education in good citizenship.

2. Social transformation (five items): The items linked with this dimension are oriented towards education for democratic citizenship, on the basis of the development of critical capacity for social analysis, (critical and creative) social thought, critical reflection and social participation in social reality. This dimension corresponds to a critical conceptualization of the Social Sciences curriculum. Its approach begins with constructivist principles and the development of critical thought, and considers the relevance of the analysis of the social problems of Humanity and daily life today. It values the ideological nature of the curriculum and teaching practice, problematizing the contents, and facilitating their construction and learning among students. From this approach "the complexity of the problems and explanatory concepts constitutes one of the principal articulations of teaching both for learning what is known and what is unknown" (Pagès 1994, p. 42).

\subsection{Design and Procedure}

A mixed investigation method that combined both qualitative and quantitative approaches was selected, employing different types of questions, techniques, and compilation, and data analysis procedures (Creswell and Plano 2007; Teddlie and Tashakkori 2009). The investigation subscribes, on the one hand, to quantitative methodological principles and to transversal ex-post facto non-experimental designs (Hernández et al. 2010). On the other hand, it is positioned among the interpretative qualitative designs through the application of content-analysis techniques, the definition of aprioristic categories (Cisterna 2005), based on the questions and the objectives of the present investigation, and the case study, the interest of which lies in the capability and depth of explanation of specific contexts (Cohen and Manion 2002).

A questionnaire was completed that was applied during the first week of the start of the study unit Investigation and Innovation in the learning of Environmental Studies (academic years 2015/2016, 2016/2017 and 2017/2018), an obligatory study unit in the fourth year specifically programmed from a critical-emancipatory curricular approach towards the teaching of History and the Social Sciences (Abellán 2014; Pagès 1994).

After the explanation of the purpose of the investigation, participants were reminded of the data privacy laws and the anonymous way in which the quantitative and qualitative data would be processed and interpreted. The qualitative information was faithfully transcribed by the investigators in the way it was expressed, avoiding any textual or discursive correction.

\subsection{Data Analysis}

Having confirmed the normal distribution of the variables of the instrument with the Kolmogorov-Smirnov $(p \geq 0.73)$ test, we completed a descriptive analysis (averages and $S D$ ) of the total data obtained and an inferential analysis (contingency tables, Pearson correlations, the student $t$-test for independent samples, single-factor ANOVA for independent groups and post hoc analysis ), with the object of confirming the existence of statistically significant differences in the scores, as a function of sex and the age groups, given the need to include social problems in the Social Sciences curriculum (dependent variable c.2). Following the atypical distribution of this variable, a logarithmic transformation was performed that reached the necessary assumed level of normality $(p=0.89)$. Likewise, this variable was also re-coded at three levels, in order to generate the contingency tables, 
in accordance with the scores that the students gave them: negative curricular necessity (1.00-4.99); low-positive curricular necessity (5.00-5.99); medium-curricular necessity (6.00-7.99); high-positive curricular necessity (8.00-8.99); and very-high-positive curricular necessity (9.00-10.00).

Finally, having confirmed the positive correlation between variables c.1-c.2 and c.3-c.2, we completed a multiple linear regression to test the influence and the magnitude of the two independent variables in the explanation of variable c.2. Likewise, we calculated the size effect of both variables on the dependent variable through a covariance analysis (ANCOVA). We used the statistical package SPSS v.24 for the treatment and analysis of the quantitative data.

The qualitative information in question c.5 was initially subjected to a careful exploratory-comparative reading of the available content, with both the object of reducing the units of analysis to significant registry units and to identify the thematic lines and the possibilities for saturation of the established aprioristic categories (Rodríguez et al. 2005): a positivist and technical, humanist and practical, and emancipatory perspective (Abellán 2014). This categorization system makes an acceptable contribution to the analysis of didactic sequences and programs and their orientation, to the observation and analysis of teaching practice, and to the promotion of critical, autonomous, and committed attitudes. Subsequently, on the basis of constant data comparisons, a deductive process of codification was conducted by which the contents were assigned to one of the three categories central to the analysis.

The students, their qualifications, their age-groups, and academic courses were all identified alphanumerically, for the identification of the participants, the organization of the registry units, and the presentation of the qualitative results: $E_{x}-T_{\text {group }}$ [student (identification number) $_{\text {-qualification }}$ ([group]-academic course) . $_{\text {. }}$.

ATLA.ti software (v. 7.5.4) was used for the analysis of the qualitative data, because of its capacity for encoding, categorization, informative saturation, and interpretation of the information that was obtained.

\section{Results}

\subsection{Quantitative Descriptive Study}

Situated in a medium range (6.00-7.99), the students evaluated the frequency with which social problems were discussed on their Degree course, with a score of $7.1(S D=1.20)$. Likewise, the score given to 'necessity to include social problems in the Social Science curriculum' is also situated on this parameter in the area of Primary Education Social Sciences $(M=6.7 ; S D=1.16)$ and the importance of its didactic treatment at this educational stage $(M=6.9 ; S D=1.74)$ (Table 3).

Table 3. EpHT Scale. Descriptive statistics by variable. (M=Mean and SD=Standard Deviation).

\begin{tabular}{cccc}
\hline Variable & $\mathbf{N}$ & $\mathbf{M}$ & SD \\
\hline c. 1 & 232 & 7.1 & 1.20 \\
c. & 232 & 6.7 & 1.16 \\
c.3 & 232 & 6.9 & 1.74 \\
c.4-1 & 232 & 7.5 & 1.30 \\
c. $4-2$ & 232 & 8.1 & 0.63 \\
c.4-3 & 232 & 8.1 & 0.59 \\
c.4-4 & 232 & 9.0 & 0.51 \\
c.4-5 & 232 & 8.1 & 0.69 \\
c.4-6 & 232 & 7.4 & 1.04 \\
c.4-7 & 232 & 7.3 & 1.03 \\
c.4-8 & 232 & 7.2 & 1.06 \\
\hline
\end{tabular}

With regard to the EpHT scale and the scores given, the trainee teachers considered that 'promoting learning, from a critical and reflexive point of view, of comprehension capacities and social analysis' 
constituted the principal end-purpose of teaching Social Sciences in Primary Education $(M=9.0$; $S D=0.51$ ), followed by 'awaken and develop the (critical and creative) social thought of the child" $(M=8.1 ; S D=0.63)$; 'educate for social intervention and transformation in a continuous process of improvement of democratic life' $(M=8.1 ; S D=0.59)$; and 'educate for the practice of democratic socialization, training the students so that they can and wish to participate in the problems of social reality' $(M=8.1 ; S D=0.69)$. The other remaining end-purposes that were proposed received scores in a medium range of 7.2 and 7.5 .

\subsection{Inferential Quantitative Study}

Having confirmed the homogeneity of the variances of the groups through the Levene statistic, the results informed us of statistically significant differences between the scores given to the necessity of incorporating social problems in the curriculum of Social Sciences as a function of $\operatorname{sex}\left(t_{(230)}=-2.431\right.$; $p=0.016)$, and the non-existence of significant differences between the age groups of the students $\left(\mathrm{F}_{(2,229)}=2.813 ; p=0.062\right)$, a circumstance confirmed in the results of the post hoc Schefee analysis (Table 4).

Table 4. Comparison of averages between groups-age.

\begin{tabular}{ccccccc}
\hline I & J & I-J & Std. Error & Sig. & \multicolumn{2}{c}{ Interval of Confidence at 95\% } \\
\cline { 5 - 6 } & & & & & Lower Limit & Upper Limit \\
\hline \multirow{2}{*}{1} & 2 & -0.210 & 0.102 & 0.121 & -0.46 & 0.04 \\
& 3 & 0.081 & 0.173 & 0.897 & -0.35 & 0.51 \\
\hline \multirow{2}{*}{3} & 1 & 0.210 & 0.102 & 0.121 & -0.04 & 0.46 \\
& 3 & 0.291 & 0.172 & 0.240 & -0.13 & 0.71 \\
\hline \multirow{2}{*}{3} & 1 & -0.081 & 0.173 & 0.897 & -0.51 & 0.35 \\
& 2 & -0.291 & 0.172 & 0.240 & -0.71 & 0.13 \\
\hline
\end{tabular}

As may be seen, $30.6 \%$ of the sample scored at very low levels (Table 5). At that level, the majority were men who gave the lowest scores to the necessity of including social problems in the Social Sciences curriculum. A majority of both men and women scored at medium levels ( men = 48.5\%; women = 52.6\%). Nevertheless, women fundamentally gave high scores with $21.5 \%$ (high positive necessity).

Table 5. Contingency table for the two variables Curricular inclusion of social problems (c.2) and Sex.

\begin{tabular}{cccccc}
\hline & & & \multicolumn{2}{c}{ Sex } & \multirow{2}{*}{ Total } \\
\cline { 3 - 5 } & & & Men & Women & \\
\hline & Low-positive necessity & f. & 38 & 33 & 71 \\
& $(5.00-5.90)$ & $\%$ & $39.2 \%$ & $24.4 \%$ & $30.6 \%$ \\
\cline { 2 - 5 } $\begin{array}{c}\text { Curricular inclusion } \\
\text { of social problems }\end{array}$ & Medium-positive necessity & f. & 47 & 71 & 118 \\
\cline { 2 - 5 } & High-positive necessity & f. & 9 & 29 & 38 \\
& $(8.00-7.99)$ & $\%$ & $9.3 \%$ & $21.5 \%$ & $16.4 \%$ \\
\cline { 2 - 5 } & Very high-positive necessity & f. & 3 & 2 & 5 \\
& $(9.00-10.00)$ & $\%$ & $3.1 \%$ & $1.5 \%$ & $2.2 \%$ \\
\hline & & f. & 97 & 135 & 232 \\
& & $\%$ & $100.0 \%$ & $100.0 \%$ & $100.0 \%$ \\
\hline
\end{tabular}

The scores by age groups are specified in Table 6 . It is notable that $50.9 \%$ of the total sample was concentrated around medium scores on the 'Curricular inclusion of social problems', all of them situated in the majority age group of the whole sample (group $2=22-23$ years; $f=66,59.5 \%$ ). 30.6\% 
were distributed between groups 1 (21-22 years) and 2, while group 1 had the highest frequencies in low-positive scores $(\mathrm{f}=38)$ as opposed to group $2(\mathrm{f}=24)$.

Table 6. Contingency table for the variables Curricular inclusion of social problems (c.2) and Age groups.

\begin{tabular}{|c|c|c|c|c|c|c|}
\hline & & & \multicolumn{3}{|c|}{ Age Groups } & \multirow{2}{*}{ Total } \\
\hline & & & 1 & 2 & 3 & \\
\hline \multirow{8}{*}{$\begin{array}{c}\text { Curricular } \\
\text { inclusion of social } \\
\text { problems }\end{array}$} & \multirow{2}{*}{$\begin{array}{l}\text { Low-positive necessity } \\
(5.00-5.90)\end{array}$} & f. & 38 & 24 & 9 & 71 \\
\hline & & $\%$ & $38.4 \%$ & $21.6 \%$ & $40.9 \%$ & $30.6 \%$ \\
\hline & \multirow{2}{*}{$\begin{array}{l}\text { Medium-positive necessity } \\
(6.00-7.90)\end{array}$} & f. & 42 & 66 & 10 & 118 \\
\hline & & $\%$ & $42.4 \%$ & $59.5 \%$ & $45.5 \%$ & $50.9 \%$ \\
\hline & \multirow{2}{*}{$\begin{array}{l}\text { High-positive necessity } \\
(8.00-8.99)\end{array}$} & f. & 19 & 16 & 3 & 38 \\
\hline & & $\%$ & $19.2 \%$ & $14.4 \%$ & $13.6 \%$ & $16.4 \%$ \\
\hline & \multirow{2}{*}{$\begin{array}{l}\text { Very high-positive necessity } \\
\qquad(9.00-10.00)\end{array}$} & f. & 0 & 5 & 0 & 5 \\
\hline & & $\%$ & $0.0 \%$ & $4.5 \%$ & $0.0 \%$ & $2.2 \%$ \\
\hline & \multirow{2}{*}{ Total } & f. & 99 & 111 & 22 & 232 \\
\hline & & $\%$ & $100.0 \%$ & $100.0 \%$ & $100.0 \%$ & $100.0 \%$ \\
\hline
\end{tabular}

The remaining scores were distributed between the high and very high levels, especially highlighting the frequencies of groups 1 and 2, with a level of representativeness of $18.6 \%$ of the total sample.

Having confirmed the existence of a high and a moderate correlation between 'The importance of covering social problems' and 'Curricular integration' ( $r=0.811 ; p=0.000)$, and the frequency of their treatment on the Degree course and their curricular integration $(r=0.556 ; p=0.000)$, we tested the causal goodness of the model and obtained satisfactory values $\left(\mathrm{F}_{(2.229)}=242.922 ; p=0.000\right)$. It is evident that the independent variables c.1 and c.3 yielded an optimum value for the variance of c. 2 of $68 \%\left(R^{2}=0.680\right)$.

The levels of linear dependence, intensity, and the relation effect confirmed that both the variable c. $1(t=3.922 ; p=0.000 ; \beta=0.173)$ and the variable c.3 $(t=16.267 ; p=0.000 ; \beta=0.719)$ jointly revealed a statistically significant effect and therefore influenced the explanation of the assessments given by the students to the necessity for the curricular inclusion of social problems. This circumstance is confirmed when assessing the analysis as control variables, sex, and age, considering that they could affect the study of the dependent variable (Table 7).

Table 7. Correlation coefficients and size effect for the variables c. 1 and c.3 on the dependent variable c.2.

\begin{tabular}{lcccccc}
\hline & $\mathbf{r}$ & $\boldsymbol{P}$ & $\mathbf{t}$ & $\boldsymbol{P}$ & $\boldsymbol{\beta}$ & $\boldsymbol{\eta}^{\mathbf{2}} \mathbf{p}$ \\
\hline c.1. Frequency & 0.556 & $0.000^{* *}$ & 3.922 & 0.000 & 0.173 & 0.063 \\
c.3. Importance & 0.811 & $0.000^{* *}$ & 16.267 & 0.000 & 0.719 & 0.536 \\
c.1. Frequency. CV (sex*age) & & & 3.382 & 0.001 & 0.147 & \\
c.3. Importance. CV (sex*age) & & & 14.068 & 0.000 & 0.687 & \\
\hline
\end{tabular}

${ }^{* *} p<0.01$ (bilateral). CV $=$ control variable.

It may therefore be confirmed that the greater the recognition of the necessity to include social problems in the Social Sciences curriculum, the greater the perceptions on the frequency with which it was covered on the Degree Course and the assessment of its importance. Likewise, we confirmed that the independent variable that had the most influence on the assessments given to the dependent variable was the importance attributed to the didactic treatment of social problems in Primary Education $(\beta=0.719)$. Equally, this variable recorded a significant effect size on the dependent variable $\left(\eta^{2} \mathrm{p}=0.536\right)$. As a consequence, the variability of the degree of curricular pertinence of social problems 
is fundamentally explained by the level of importance given to the didactic treatment of social problems in Primary Education.

\subsection{Qualitative Study}

The responses given to the open question c.5 ('According to your opinion and Degree Course, what social end-purpose and objectives would have to be covered in the teaching of History in Primary Education?') were explained from two or three established aprioristic categories (positivist and technical perspectives, as well as critical and emancipatory perspectives), without obtaining adequate definitions for the humanist and practical category. Exactly $48 \%$ of the responses attributed an instructive social function, in the current social panorama, to the teaching of History at school.

The end-purposes of teaching and learning History linked with this category are directed at offering a representation of the past as an explanatory axis of current political realities, which is, History at school as magistra vitae in the management of contemporary societies. From this perspective, the teaching and learning of History is oriented towards the acquisition of objective historical and social knowledge, neutral and universalist, the identification of the principal ideas of historical and social discourses, and the preparation of an "enunciative, descriptive, and schematic discourse" (Abellán 2014, p. 104). History that is taught in the scientific field is articulated around reproductive mechanisms of the curricular regulations and the fundamental figures and processes for the construction of the national identity. Likewise, this approach is founded on the recognition of the existence of a single past, explaining a common cultural inheritance:

Knowing the historic past, analyzing historic events to learn about the success and not to repeat mistakes $\left(\mathrm{E}_{34}\right.$-Primary $\left.4[1]-15 / 16\right)$

The main end-purpose would be to know world history with its great conflicts thinking about the reasons and the consequences, in such a way that, when you know your history, you're not condemned to repeat it $\left(\mathrm{E}_{25}\right.$-Primaria $\left.4[2]-15 / 16\right)$

Those contents that are picked up with the intention of social progress [which] we are capable of reflecting upon so as not to repeat the mistakes of the past $\left(\mathrm{E}_{78}\right.$-Primary $\left.{ }_{4[2]-16 / 17}\right)$

The end-purpose of History is to understand the present through knowledge of past events and their evolution. This will avoid committing the same mistakes in the future [ . . ] ( $\mathrm{E}_{152}$-Primary $\left.4[3]-16 / 17\right)$

The social end-purpose and the most important objective is that the students always know how to improve as people, taking as an example what has happened in the past (E ${ }_{181}$-Primary $\left.4[1]-17 / 18\right)$

Sensitivity to children with the education of 21st century and guidance to improve that education taking into account all the mistakes made in History $\left(\mathrm{E}_{203}\right.$-Primary $\left.4[1]-17 / 18\right)$

Along these lines, there are significant affirmations (32\%) in support of a scholarly History, understood in terms of traditional chronological, political, and hegemonic parameters. In these responses, the selection of content and the formulation of objectives is dependent on technical-reproductive proposals oriented towards "knowing the facts that have meant we are who we are" (E96-Primary4[2]-16/17):

The primary objective would be that students know the passage of the different economic and political historical events until passing on to the current ones, and that they understand and properly construct the historical contents of the curriculum of the study unit $\left(\mathrm{E}_{65}\right.$-Primary $\left.4[1]-15 / 16\right)$

Students must understand the events that have marked the History of our past and its societies, so that they can understand current history and behave as good citizens ( $\mathrm{E}_{44}$-Primary $\left.4[2]-15 / 16\right)$ 
Explain where we came from (characteristics, stages ... ). Recognize differences between stages. Study regional communities, provinces, capitals, rivers ... of Spain. Describe political, economic, social, and cultural characteristics of Spain ( $\mathrm{E}_{121}$-Primary $\left.4[2]-16 / 17\right)$

Know the most important facts of History, above all, in Spain, and the stages through which we have passed throughout our time ( $\mathrm{E}_{198}$-Primaria 4 -[3]17/18)

From among the responses, $20 \%$ of the students also supported the social function and the objectives of History teaching in education for democratic, global, egalitarian, and inclusive citizenship, which begins with the assumption of Human Rights. A social function that, the students point out, guarantees the "training in critical thought [ ... ]" (E "[ ... ] social and civic responsibility before the problems of the present" (E83-Primary4[2]-16/17).

In the critical and emancipatory category, education for the democratic exercise of a plural and diverse citizenship is defined as one of the principal end-purposes of teaching and learning History. Through this approach, the aim is "create a willingness in the student, so that, through critical comprehension of the present reality, the student will wish to think and to intervene in the construction of the future" (Abellán 2014, p. 105). Democratic values and the development of historic thought, empathy, imagination, and historic creativity have to be useful to approach social problems, and to apply social and historic knowledge to the proposals for the resolution of social problems.

To construct your identity as a citizen from various perspectives: the individual, the collective, and globally, in order to conduct ourselves properly in the diversity of the current world, respecting the rest and knowing that we also should be respected ( $\mathrm{E}_{13}$-Primary $\left.4[1]-15 / 16\right)$

To train active citizens with a commitment towards an inclusive society. To train critical people capable of relating what happened before with what is happening now and not only learn it without any discussion ( $\mathrm{E}_{5}$-Primary4[2]-15/16)

Education directed towards the edification of democratic and free people, with social, human, and civic values. People who respect rights and obligations, as well as the identities of the other; people who respect and tolerate plurality and globality. In addition, History teaching should be based on developing the capabilities of students, in order to [...] understand geographic, sociological, and historic aspects and, by doing so, they can interpret the reality in which they live and they can intervene in it (E90-Primary 4[2]-16/17)

Education for citizenship with critical thought, knowledge of Human Rights and of social problems, so that solutions may be put forward ( $\mathrm{E}_{142}$-Primary4[1]-16/17)

To develop the critical capability [of the student] and to promote an active consciousness. To promote an inclusive democratic society, where no differentiations exist between classes and where the whole world has the same rights and opportunities, whether men or women ( $\mathrm{E}_{170}$-Primary $\left.4[2]-17 / 18\right)$

To prepare the student as an active citizen in society, educating for democratic and inclusive citizenship, in which Human Rights are respected, as well as having a critical capacity [for the analysis] of social events ( $\mathrm{E}_{169}$-Primary4[3]-17/18)

\section{Discussion and Conclusions}

While the students highlighted the development and learning of comprehensive and analytical skills and the analysis of social reality as among the most prominent end-purposes in the teaching of the Social Sciences, students also attached average scores to the importance of the didactic treatment of social problems and the need to include them in the Primary Education curriculum. Likewise, these results informed us of statistically significant differences between the scores as a function of sex. According to the studies by Ortega-Sánchez $(2017,2019)$ and Ortega-Sánchez and Pagès (2018), one of 
the possible interpretations of this difference can be found in the explicit female recognition of gender inequalities as a social problem and in the identification of the invisibility of women in the traditional historical narrative. Their educational potential appeared to be unconnected to the most highly valued end-purpose: the development of social, critical, and creative thought. In contrast, the research of Souto (2015) on the attitudes and the competences of Primary Education teachers and Geography and History teachers states that, in their majority, trainee teachers selected the affirmation that "the teacher must have, above all, an attitude of knowing the great social problems of the contemporary world so that they are the object of scholarly analysis" (p. 41), and the capability "to select social and environmental problems that will be studied in the educational contents". These affirmations can also be found in the research of Byford et al. (2009) on the attitudes of teachers towards the teaching of controversial questions in the classroom. Likewise, the studies on the recent standardized evaluations of the Organic Law for the Improvement of Educational Quality (LOMCE) confirm the possibilities of the students giving mature explanations, on the basis of evaluative designs that consider capabilities for solving social problems (Souto et al. 2014).

The results of the open question, however, point toward the need for History teaching at school as magistra vitae, one of the end-purposes with the lowest scores EpHT $(M=7.3 ; S D=1.03)$. In fact, $80 \%$ of students adopted the position of a positivist-technical curricular approach towards the teaching of History, as against the $20 \%$ that adopted a critical-emancipatory approach. This last approach to the teaching of History is directed towards education for good citizenship that helps students move towards the critical analysis of information (Ross 2004) and to follow the construction of social knowledge from its unfinished structure. Nevertheless, this proposed approach appears not to be having a real impact in practice (Vázquez 2014), in that the social problems could make the management of social reality possible. Along these lines, the investigation of Harris and Clarke (2011) was developed on the challenge of approaching cultural diversity and ethnicity in the British History curriculum and, more recently, the study by Woolley (2017), in which the need to promote the diversity of interpretations and the presence of multiple perspectives is affirmed in response to the teaching of controversial and polemical topics in the history classroom.

The results obtained in the present investigation reaffirm those obtained in the investigation of Abellán (2014), where the dependence on school textbooks is noted, and the persistence of representations on the meaning of teaching and learning linked to a technical curricular model. Likewise, the conclusions reached in the investigation by Canals (2015) in teacher training contexts consider that "the quality of social thought that students construct, when they present their points of view talking of current social problems related with the contents of the study unit, is quite poor" (Canals 2015, p. 452).

In this sense, the investigation by Castellví (2018) on the construction of stories about relevant local social problems among Primary Education students from the final phases affirmed their difficulties over constructing stories on relevant social topics in a coherent, reflective, and critical way. Teacher training from the principles of critical literacy could be the impetus for action, social commitment, and intervention in social problems, and the development of democratic consciousness (Ortega-Sánchez and Pagès 2017b).

Likewise, the assessment of the degree of importance of the didactic treatment of social problems and socially alive questions during Primary Education, in a predictive and prominent way, influence their explicit integration in the Social Sciences curriculum. These results coincide with those obtained in the investigation of Ortega-Sánchez and Pagès (2016). Along those lines, the investigation of De Alba and Navarro (2017) on education in History and good citizenship among students completing their Bachiller studies shows the need to consider the curriculum as a dynamic construction, which is necessarily adapted to social change. The strengthening of democratic learning would therefore move on to "organizing the curriculum through socially relevant problems" (p. 93). A need was also found in the investigation by González and Sant (2014), where the affirmation of both active and 
trainee-teachers was noted of the importance of working content linked to socially relevant problems of good citizenship.

The reproduction of traditional curricular approaches in teaching practices hides the daily social problems that confront participative citizenship. The end-purpose of teaching History and Social Sciences has therefore to lead to perspectives based on controversial topics, relevant social problems, and socially alive questions, which are at the foundation of our daily life and that sustain the development of social and citizenship-based competences (Éthier and Lefrançois 2008; Heimberg 2010; Hess 2004; Pagès and Santisteban 2011).

Author Contributions: Conceptualization, D.O.-S. and J.P.B.; methodology, D.O.-S.; software, D.O.-S.; validation, D.O.-S.; formal analysis, D.O.-S.; investigation, D.O.-S. and J.P.B.; resources, D.O.-S. and J.P.B.; data curation, D.O.-S. and J.P.B.; writing — original draft preparation, D.O.-S. and J.P.B.; writing—-review and editing, D.O.-S. and J.P.B.; supervision, J.P.B. All authors have read and agreed to the published version of the manuscript.

Funding: This research received no external funding.

Acknowledgments: The study was approved by the research project EDU2016-80145-P (Ministry of Economy and Business of Spain), and by the Research Group of the University of Burgos of Didactics of History and Social Sciences (DHISO).

Conflicts of Interest: The authors declare no conflict of interest.

\section{References}

Abellán, Jordi. 2014. La reflexión sobre las finalidades de la enseñanza de la Historia. Un estudio de caso en la formación inicial del profesorado en el sistema educativo mexicano. Doctoral thesis, Universitat Autònoma de Barcelona, Bellaterra, Spain. Available online: https://dd.uab.cat/record/132348?ln=ca (accessed on 13 April 2019).

Benejam, Pilar, and Joan Pagès. 1997. Enseñar y aprender Ciencias Sociales. Geografía e Historia en la Educación Secundaria. Barcelona: Institut de Ciències de l'Educació/Universitat de Barcelona/Horsori.

Bronckbank, Anne, and Ian McGill. 2007. Facilitating Reflective Learning in Higher Education. Berkshire and New York: Open University Press-McGraw-Hill.

Byford, Jeff B., Sean Lennon, and William B. Russell. 2009. Teaching Controversial Issues in the Social Studies: A Research Study of High School Teachers. The Clearing House: A Journal of Educational Strategies 82: 165-70. [CrossRef]

Canal, Marta, Daniel Costa, and Antoni Santisteban. 2012. El alumnado ante problemas sociales relevantes: ¿Cómo los interpreta? ¿Cómo piensa la participación? In Educar para la participación ciudadana en la enseñanza de las Ciencias Sociales. Edited by Nicolás de Alba, Francisco. F. García-Pérez and Antoni Santisteban. Seville: AUPDCS-Díada Editora, vol. 1, pp. 527-35.

Canals, Roser. 2015. El desarrollo del pensamiento social en la formación inicial del profesorado para dar respuesta a problemas sociales invisibles desde el currículo. In Una enseñanza de las Ciencias Sociales para el futuro: Recursos para trabajar la invisibilidad de personas, lugares y temáticas. Edited by Ana María Hernández, Carmen R. García and Juan L. de la Montaña. Cáceres: University of Extremadura-AUPDCS, pp. 447-56.

Castellví, Jordi. 2018. La construcción de relatos sobre problemas sociales relevantes locales de alumnos de ciclo superior de Primaria en la era digital. In Buscando formas de enseñar: Investigar para innovar en Didáctica de las Ciencias Sociales. Edited by Esther López, Carmen R. García and María Sánchez. Valladolid: Universidad de Valladolid-AUPDCS, pp. 965-74.

Cisterna, Francisco. 2005. Categorización y triangulación como procesos de validación del conocimiento en investigación cualitativa. Theoria 14: 61-71.

Claire, Hilary, and Cathie Holden. 2007. The Challenge of Teaching Controversial Issues. Trentham Books: Stoke on Trent.

Cohen, Louis, and Lawrence Manion. 2002. Métodos de investigación educativa. Madrid: La Muralla.

Creswell, John. W., and Vicki L. Plano. 2007. Designing and Conducting Mixed Methods Research. Thousand Oaks: SAGE Publications. 
De Alba, Nicolás, and Elisa Navarro. 2017. La educación para la ciudadanía a través de la enseñanza de la Historia: Estrategias de mejora para el centro, el docente y el currículum. Giornale Italiano della Ricerca Educativa-Italian Journal of Educational Research, 89-98.

De Alba Fernández, Nicolás, Francisco F. García-Pérez, and Antoni Santisteban, eds. 2012. Educar para la participación ciudadana en la enseñanza de las Ciencias Sociales. Seville: AUPDCS-Díada.

Díaz, Naira, and María del Mar de la Fuente. 2017. Problemas sociales relevantes en el aula de primaria: La "cartografía de la controversia" como método. REIDICS. Revista de Investigación en Didáctica de las Ciencias Sociales 1: 24-38.

Éthier, Marc-André, and David Lefrançois. 2008. Investigación sobre el desarrollo de competencias en ciencias sociales a partir de prácticas políticas y comunitarias. Íber. Didáctica de las Ciencias Sociales, Geografía e Historia 58: 89-107.

Evans, Ronald W., and David W. Saxe, eds. 1996. Handbook on Teaching Social Issues. Washington, DC: NCSS.

Ezzedeen, Souha R. 2008. Facilitating Class Discussions around Current and Controversial Issues: Ten Recommendations for Teachers. College Teaching 56: 230-36. [CrossRef]

García-Pérez, Francisco F. 2014. Ciudadanía participativa y trabajo en torno a problemas sociales y ambientales. In Una mirada al pasado y un proyecto de futuro. Investigación e Innovación en Didáctica de las Ciencias Sociales. Edited by Joan Pagès and Antoni Santisteban. Barcelona: Universitat Autònoma de Barcelona-AUPDCS, vol. 1, pp. 119-25.

González, Gustavo A. 2013. El profesorado en formación y las finalidades de la enseñanza de las Ciencias Sociales. Unipluri/versidad 13: 24-34.

González, Gustavo A., and Edda Sant. 2014. ¿Que debe saber el profesorado para educar a ciudadanos críticos y participativos? In Una mirada al pasado y un proyecto de futuro. Investigación e Innovación en Didáctica de las Ciencias Sociales. Edited by Joan Pagès and Antoni Santisteban. Barcelona: Universitat Autònoma de Barcelona-AUPDCS, vol. 2, pp. 295-304.

Grau, Víctor. 2016. El valor de la alteridad: Enseñanza-aprendizaje a partir de realidades problemáticas temporales. In Deconstruir la alteridad desde la Didáctica de las Ciencias Sociales: educar para una ciudadanía global. Edited by Carmen R. García, Aurora Arroyo and Beatriz Andreu. Las Palmas: Universidad de Las Palmas de Gran Canaria-AUPDCS, pp. 58-66.

Hand, Michael, and Ralph Levinson. 2012. Discussing Controversial Issues in the Classroom. Educational Philosophy and Theory 44: 614-29. [CrossRef]

Harris, Richard, and Gill Clarke. 2011. Embracing diversity in the history curriculum: A study of the challenges facing trainee teachers. Cambridge Journal of Education 41: 159-75. [CrossRef]

Hawley, Todd S., Alicia R. Crowe, and Evan Mooney. 2016. Visualizing Social Justice: Using Controversial Images in Social Studies Classrooms. The Clearing House: A Journal of Educational Strategies, Issues and Ideas 89: 85-90. [CrossRef]

Heimberg, Charles. 2010. ¿Cómo puede orientarse la educación para la ciudadanía hacia la libertad, la responsabilidad y la capacidad de discernimiento de las nuevas generaciones? Íber: Didáctica de las Ciencias Sociales, Geografía e Historia 64: 48-57.

Hernández, Lorenia. 2013. La enseñanza de las Ciencias Sociales en la formación profesional de las estudiantes de maestra de Educación Infantil. Doctoral thesis, Universitat Autònoma de Barcelona, Bellaterra, Spain. Available online: https://ddd.uab.cat/record/115328?ln=ca (accessed on 25 August 2019).

Hernández, Roberto, Carlos Fernández, and María del Pilar Baptista. 2010. Metodología de la investigación. México: McGraw-Hill.

Hess, Diana E. 2004. Controversies about controversial issues in democratic education. PS: Political Science $\mathcal{E}$ Politics 37 2: 257-61.

Ho, Li-Ching, and Tricia Seow. 2015. Teaching Controversial Issues in Geography: Climate Change Education in Singaporean Schools. Theory E Research in Social Education 43: 314-44.

Huddleston, T. 2005. Teacher training in citizenship education: Training for a new subject or for a new kind of subject? Journal of Social Science Education 4: 50-63.

Hung, Yu-Han. 2019. To teach or not teach controversial public issues in Taiwan? Asia Pacific Journal of Education 39: 562-76. [CrossRef]

Jerome, Lee, and Alex Elwick. 2019. Teaching about terrorism, extremism and radicalisation: Some implications for controversial issues pedagogy. Oxford Review of Education 1-16. [CrossRef] 
Kello, Katrin. 2016. Sensitive and controversial issues in the classroom: Teaching history in a divided society. Teachers and Teaching 22: 35-53. [CrossRef]

King, John T. 2009. Teaching and Learning about Controversial Issues: Lessons from Northern Ireland. Theory $\mathcal{E}$ Research in Social Education 37: 215-46.

Legardez, Alain. 2003. L'enseignement des questions sociales et historiques, socialement vives. Le Cartable de Clio 3: $245-53$.

Levstik, Linda S., and Cynthia A. Tyson, eds. 2008. Handbook of Research in Social Studies Education. New York and London: Routledge.

Marcus Alan S., Jeremy D. Stoddard. 2009. The Inconvenient Truth about Teaching History with Documentary Film: Strategies for Presenting Multiple Perspectives and Teaching Controversial Issues. The Social Studies 100: 279-84. [CrossRef]

Martínez, Iván A. 2017. ¡Profe, enséñame con canciones! Una investigación sobre el uso de las canciones en la enseñanza y aprendizaje de las Ciencias Sociales. Doctoral Thesis, Universitat Autònoma de Barcelona, Bellaterra, Spain. Available online: https://ddd.uab.cat/record/187750?ln=ca (accessed on 5 June 2019).

Martínez, María Dolores Jiménez, and Concepción Moreno. 2012. Formar para enseñar en participación ciudadana. Una experiencia integradora. In Educar para la participación ciudadana en la enseñanza de las Ciencias Sociales. Edited by Nicolás de Alba, Francisco F. García-Pérez and Antoni Santisteban. Seville: AUPDCS-Díada Editora, vol. 2, pp. 511-19.

Martínez, Iván A., and Joan Pagès. 2017. Aprender Historia y Ciencias Sociales utilizando las canciones. Resultados de una investigación. Clío \& Asociados. La historia enseñada 24: 83-99.

Misco, Thomas. 2013. 'We do not talk about these things': The promises and challenges of reflective thinking and controversial issue discussions in a Chinese high school. Intercultural Education 24: 401-16. [CrossRef]

Misco, Thomas, and Lena Lee. 2014. "There is no such thing as being Guamanian": Controversial Issues in the Context of Guam. Theory \& Research in Social Education 42: 414-39.

Nganga, Lydiah, Amy Roberts, John Kambutu, and Joanie James. 2020. Examining pre-service teachers' preparedness and perceptions about teaching controversial issues in social studies. The Journal of Social Studies Research 44: 77-90. [CrossRef]

Ortega-Sánchez, D. 2017. Las mujeres en la enseñanza de la Historia y de las Ciencias Sociales: estudio de caso en formación inicial de maestros y maestras de Educación Primaria. Doctoral thesis, Universitat Autònoma de Barcelona, Bellaterra, Spain. Available online: https://ddd.uab.cat/record/187752 (accessed on 15 October 2019).

Ortega-Sánchez, Delfín. 2019. Teaching Gender in the History Classroom: An Investigation into the Initial Training of Primary Education Teachers. Education Sciences 9: 114. [CrossRef]

Ortega-Sánchez, Delfín, and Joan Pagès. 2016. Deconstruyendo la alteridad femenina en la enseñanza de la Historia escolar: representaciones sociales del profesorado de educación primaria en formación. In Deconstruir la alteridad desde la Didáctica de las Ciencias Sociales: Educar para una ciudadanía global. Edited by Carmen R. García, Aurora Arroyo and Beatriz Andreu. Las Palmas: Universidad de Las Palmas de Gran Canaria-AUPDCS, pp. 184-93.

Ortega-Sánchez, Delfín, and Joan Pagès. 2017a. Las representaciones sociales de los problemas contemporáneos en estudiantes de Magisterio de Educación Primaria. Investigación en la Escuela. Revista internacional de investigación e innovación educativa 93: 1-16. [CrossRef]

Ortega-Sánchez, Delfín, and Joan Pagès. 2017b. Literacidad crítica, invisibilidad social y género en la formación del profesorado de Educación Primaria. REIDICS. Revista de Investigación en Didáctica de las Ciencias Sociales 1: 102-17.

Ortega-Sánchez, Delfín, and Joan Pagès. 2018. La construcción de identidades de género en la enseñanza de la Historia escolar: Un estudio a partir de las narrativas históricas de los futuros y futuras docentes en Educación Primaria. In Buscando formas de enseñar: Investigar para innovar en Didáctica de las Ciencias Sociales. Edited by Esther López, Carmen R. García and María Sánchez. Valladolid: Universidad de Valladolid-AUPDCS, pp. 89-100.

Oulton, Christopher, Vanessa Day, Justin Dillon, and Marcus Grace. 2004. Controversial issues-Teachers' attitudes and practices in the context of citizenship education. Oxford Review of Education 30: 489-507. [CrossRef]

Pace, Judith L. 2019. Contained risk-taking: Preparing preservice teachers to teach controversial issues in three countries. Theory \& Research in Social Education 47: 228-60. 
Pagès, Joan. 1994. La Didáctica de las Ciencias Sociales, el currículum de historia y la formación del profesorado. Signos. Teoría y práctica de la educación 13: 38-51.

Pagès, Joan. 2002. Aprender a enseñar Historia y Ciencias Sociales: El currículo y la Didáctica de las Ciencias Sociales. Pensamiento Educativo 30: 255-69.

Pagès, Joan. 2007. La enseñanza de las ciencias sociales y la educación para la ciudadanía en España. Didáctica geográfica 9: 205-14.

Pagès, Joan. 2015. La educación política y la enseñanza de la actualidad en una sociedad democrática. Educaçâo em Foco 19: 17-37.

Pagès, Joan, and Antoni Santisteban. 2011. Les qüestions socialment vives i l'ensenyament de les Ciències Socials. Barcelona: Universitat Autònoma de Barcelona.

Pagès, Joan, and Antoni Santisteban. 2014. Una mirada del pasado al futuro en la Didáctica de las Ciencias Sociales. In Una mirada al pasado y un proyecto de futuro. Investigación e Innovación en Didáctica de las Ciencias Sociales. Edited by Joan Pagès and Antoni Santisteban. Barcelona: Universitat Autònoma de Barcelona-AUPDCS, vol. 1, pp. 17-39.

Perrenoud, Philippe. 2011. Desarrollar la práctica reflexiva en el oficio de enseñar. Barcelona: Graó.

Pollak, Italy, Aliza Segal, Adam Lefstein, and Assaf Meshulam. 2017. Teaching controversial issues in a fragile democracy: Defusing deliberation in Israeli primary classrooms. Journal of Curriculum Studies 50: 387-409. [CrossRef]

Reiss, Michael J. 2019. Evolution education: Treating evolution as a sensitive rather than a controversial issue. Ethics and Education 14: 351-66. [CrossRef]

Rodríguez, Clemente, Oswaldo Lorenzo, and Lucía Herrera. 2005. Teoría y práctica del análisis de datos cualitativos. Proceso general y criterios de calidad. Revista Internacional de Ciencias Sociales y Humanidades 15: 133-54.

Ross, E. Wayne. 2004. Social Studies and Critical Thinking. Kincheloe. In Critical Thinking and Learning: An Encyclopedia for Parents and Teachers. Edited by Danny K. Weil and Joe L. Kincheloe. Westport: Greenwood Publishing Group, pp. 383-88.

Santisteban, Antoni. 2009. Cómo trabajar en clase la competencia social y ciudadana. Aula de Innovación Educativa 187: 12-15.

Santisteban, Antoni. 2012. La investigación sobre el desarrollo de la competencia social y ciudadana para una participación crítica. In Educar para la participación ciudadana en la enseñanza de las Ciencias Sociales. Edited by Nicolás de Alba, Francisco F. García-Pérez and Antoni Santisteban. Seville: AUPDCS-Díada Editora, vol. 1, pp. 277-86.

Santisteban, Antoni. 2015. La formación del profesorado para hacer visible lo invisible. In Una enseñanza de las Ciencias Sociales para el futuro: Recursos para trabajar la invisibilidad de personas, lugares y temáticas. Edited by Ana María Hernández, Carmen R. García and Juan L. de la Montaña. Cáceres: University of Extremadura-AUPDCS, pp. 383-93.

Segall, Avner, and William Gaudelli. 2007. Reflecting Socially on Social Issues in a Social Studies Methods Course. Teaching Education 18: 77-92. [CrossRef]

Souto, Xosé M. 2015. Hacemos visible la hipocresía social en las actividades escolares. In Una enseñanza de las Ciencias Sociales para el futuro: Recursos para trabajar la invisibilidad de personas, lugares y temáticas. Edited by Ana María Hernández, Carmen R. García and Juan L. de la Montaña. Cáceres: University of Extremadura-AUPDCS, pp. 23-48.

Souto, Xosé. M., Carlos Fuster, and Jorge Sáiz. 2014. Un camino de ida y vuelta: Revalidas y selectividad en las rutinas escolares de la enseñanza de la Geografía e Historia. In Una mirada al pasado y un proyecto de futuro. Investigación e Innovación en Didáctica de las Ciencias Sociales. Edited by Joan Pagès and Antoni Santisteban. Barcelona: Universitat Autònoma de Barcelona-AUPDCS, vol. 2, pp. 157-66.

Swalwell, Katy, and Simone Schweber. 2016. Teaching through Turmoil: Social Studies Teachers and Local Controversial Current Events. Theory E Research in Social Education 44: 283-315.

Teddlie, Charles, and Abbas Tashakkori. 2009. Foundations of Mixed Methods Research: Integrating Quantitative and Qualitative Approaches in the Social and Behavioral Sciences. Thousand Oaks: SAGE Publications.

Ten Dam, Greet, and Monique Volman. 2004. Critical thinking as a citizenship competence: Teaching strategies. Learning and Instruction 14: 359-79. [CrossRef] 
Vázquez, Felicia. 2014. El pensamiento docente en relación a la Historia en un contexto de enseñanza situada. In Una mirada al pasado y un proyecto de futuro. Investigación e Innovación en Didáctica de las Ciencias Sociales. Edited by Joan Pagès and Antoni Santisteban. Barcelona: Universitat Autònoma de Barcelona-AUPDCS, vol. 2, pp. 651-58.

Villalón, Gabriel, and Joan Pagès. 2013. ¿Quién protagoniza y cómo la historia escolar? La enseñanza de la historia de los otros y las otras en los textos de estudio de Historia de Chile de educación primaria. Clío E Asociados. La historia enseñada 17: 119-36.

Washington, Elizabeth Yeager, and Emma K. Humphries. 2011. A Social Studies Teacher's Sense Making of Controversial Issues Discussions of Race in a Predominantly White, Rural High School Classroom. Theory $\mathcal{E}$ Research in Social Education 39: 92-114.

Woolley, Mary C. 2017. The attitudes and perceptions of beginning teachers in relation to teaching controversial issues in the history classroom. Revista Electrónica Interuniversitaria de Formación del Profesorado 20: 1-16. Available online: http://revistas.um.es/reifop/article/view/284561 (accessed on 10 June 2019). [CrossRef]

(C) 2020 by the authors. Licensee MDPI, Basel, Switzerland. This article is an open access article distributed under the terms and conditions of the Creative Commons Attribution (CC BY) license (http://creativecommons.org/licenses/by/4.0/). 